\title{
Effect of Intelligent Irrigation Technique on Water Use Efficiency for Cucumber and Pepper Crops in New Salhia Area
}

\author{
A. A. Abdel-Aziz \\ Soil Chemistry and Physics Department - Desert Research \\ Center
}

\begin{abstract}
7 THE INTELLIGENT irrigation technique is a valuable tool for scheduling irrigation and quantifying water required by plants to achieve water savings. Field experiments were carried out in New Salhia area, El- Sharqia Governorate, Egypt, at $\left(30^{\circ} 18^{`} \mathrm{~N}\right.$ : $31^{\circ} 23^{`} \mathrm{E}$. $27 \mathrm{~m}$ a.s.l) during the summer season of 2015.The main objectives were to investigate the effectiveness of the intelligent irrigation technique (IIT) (Hunter Pro-C (H)) which was irrigated automatically on water use efficiency (WUE) and irrigation water use efficiency (IWUE) for irrigation scheduling of cucumber (Cucumis sativus Hayle) and pepper (Capsicum annuum) crops. The intelligent irrigation technique, (IIT) was implemented and tested under surface, (SDI) and sub-surface drip irrigation systems, (SSDI). The results obtained with these systems were consequently compared to that of the irrigation control technique (ICT), which was irrigated manually based on crop evapotranspiration (ETc) values. The results revealed that cucumber and pepper growth parameters except $p H$ of juice were significantly increased by IIT under SSDI. In addition; IIT under SSDI conserved 34 and $24 \%$ of total applied irrigation water for cucumber and pepper respectively. Moreover, the results showed that the IIT under SSDI recorded significant increase 12 and $13 \%$ for marketable yield Ym of cucumber and pepper respectively. While, the results reported that the WUE values using IIT under SSDI were significantly increased by about 30 to $33 \%$ for cucumber and pepper respectively. The results confirmed also that the values of IWUE at IIT under SSDI were significantly increased by about 49 to $39 \%$ for cucumber and pepper respectively. The intelligent irrigation technique may provide a valuable tool for scheduling irrigation in cucumber and pepper farming and may be extendable for use in other similar agricultural crops. These results show that this IIT could be a flexible, practical tool for improving scheduled irrigation. Hence, this technique can therefore be recommended for efficient automated irrigation systems that produces higher yield and conserves large amounts of irrigation water.
\end{abstract}

Keywards: Intelligent irrigation, Water use efficiency, Cucumber, Pepper, Drip irrigation

Water scarcity and drought are the major factors constraining agricultural crop production in arid and semi-arid zones of the world; therefore innovations for saving water in irrigated agriculture and thereby improving water use efficiency are of paramount importance in water-scarce regions. In Egypt farmers have been using 
manual control techniques for irrigation. In this process, plants didn't receive the same amounts of irrigation water all over the field. Therefore, adoption of modern irrigation techniques is needed to increase water use efficiency and high productivity while minimizing irrigation water needed (Acar et al., 2010). In the past 10 years, intelligent irrigation technique (IIT) has been developed by a number of manufacturers and has been promoted by water purveyors in an attempt to reduce over-irrigation (Michael and Dukes, 2008). The irrigation controller regulates the desired moisture level in agricultural soil by making the irrigation pump on or off based on the sensor readings. It provides science basis for using water resources under the technologies of soil moisture sensors, temperature sensors, precise irrigation equipment, intelligent fuzzy controller, and computer-controlled devices, so that agricultural irrigation get the best part out of water utilization (Patil et al., 2012). Meanwhile, the amount of water given to the plants depends on its size, and moisture control of soil. The moisture of soil is affected by temperature of environment, evaporation due to wind velocity and the water budget. Accordingly we need to monitor the parameters like atmospheric temperature, humidity, wind speed and direction, water radiation, soil temperature, sunshine and rain fall, etc., Based on these parameters, needed water should to given for the plants, based on its growth stages (Anand and Perinbam, 2014). There were many intelligent irrigation techniques (IIT) available and were used to compute crop water requirements based on climatic data. Usually, intelligent irrigation was integrated with smart controllers and using microclimatic data to schedule irrigation water (Nautiyal et al., 2010). Currently, there were a number of intelligent irrigation systems that can operate without human intervention. The smart controllers integrate many disciplines to produce a significant improvement in crop production and resource management (Norum and Adhikari, 2009). Intelligent irrigation technologies were evaluated and results indicate up to $43 \%$ (average 38\%) water savings over conventional irrigation control methodologies (Dassanayake et al., 2009). Intelligent irrigation IIT treatments of tomato yield were 39 and 40.08 ton $^{-1}$ for both seasons, respectively. Moreover, the amounts of applied irrigation water were 5947.6 and $6337.6 \mathrm{~m}^{3} \mathrm{~h}^{-1}$ for actual evapotranspiration ETa seasons, respectively. However, the results indicate that irrigation water was used more effectively through IIT treatment. The comparison of the IIT with the ICS shows that the increases in IWUE were 39\% and $47 \%$ for the 2010 and 2011 seasons, respectively. In contrast, the smallest amount of irrigation water used was $594.76 \mathrm{~mm}$ in case of IIT; while the largest amount applied IR was $854.79 \mathrm{~mm}$ in the ICS treatment. (Mohamed et al., 2013 and AlGhobari et al., 2013).

The effect of three irrigation methods [subsurface drip (SSD), surface drip (SD) and furrow irrigation (FI)] on yields; water saving and irrigation water use efficiency (IWUE) on corn. The highest yield was obtained with SSD and the lowest was obtained with the FI method (Hassanli et al., 2009).

The main objectives were to investigate the effectiveness of the intelligent irrigation technique which was irrigated automatically on water use efficiency and irrigation water use efficiency compared to traditional technique for irrigation scheduling of cucumber and pepper crops under surface and sub-surface drip

Egypt. J. Soil Sci. 56, No. 4 (2016) 
irrigation systems and show any technique give maximum production with minimum applied irrigation water.

\section{Experimental \\ Materials and Methods}

Field experiments were carried out in New Salhia area, El- Sharqia Governorate, Egypt, at ( $30^{\circ} 18^{`} \mathrm{~N}: 31^{\circ} 23^{`}$ E. $27 \mathrm{~m}$ a.s.1) during the summer season of 2015 . In split plot design with three replicates, the experimental was divided into $40 \mathrm{~m}^{2}$ plots; each bounded by $1.5 \mathrm{~m}$ wide barren to avoid horizontal infiltration. The obtained data were subjected to statistical analysis according to Snedecor and Cochran (1989) using Costate software program. Figure (1). Shows the cucumber (Cucumis sativus Hayle) and pepper (Capsicum annuum) cultivated using two irrigating techniques namely, 1). Intelligent irrigation (Hunter Pro-C (H)) IIT, which was irrigated automatically, based on soil moisture sensors for all depths and automatic weather station; 2). Irrigation control ICT as irrigation water was applied manually based on crop evapotranspiration (ETc) values, calculated using metrological data from weather station of the area, taking in to consideration that leaching requirements and drip irrigation efficiency were added. All techniques were tested under surface (SDI) and sub-surface drip irrigation systems (SSDI).

Soil management practices were applied using doses of fertilizer as recommended by the Ministry of Agriculture and land reclamation.

The leaf area LA $\left(\mathrm{cm}^{2}\right)$, fruit length $\mathrm{L}(\mathrm{cm})$, fruit diameter D $(\mathrm{cm})$, total soluble solid TSS $(\%)$, pH of juice and marketable yield $\mathrm{Ym}\left(\mathrm{Mg} \mathrm{fed}^{-1}\right)$ were determined. Water use efficiency WUE $\left(\mathrm{kg} \mathrm{m}^{-3}\right)$, irrigation water use efficiency IWUE $\left(\mathrm{kg} \mathrm{m}^{-3}\right)$ and actual evapotranspiration ETa $(\mathrm{mm})$, were calculated for different applied irrigating techniques and irrigation system under cucumber and pepper plots.

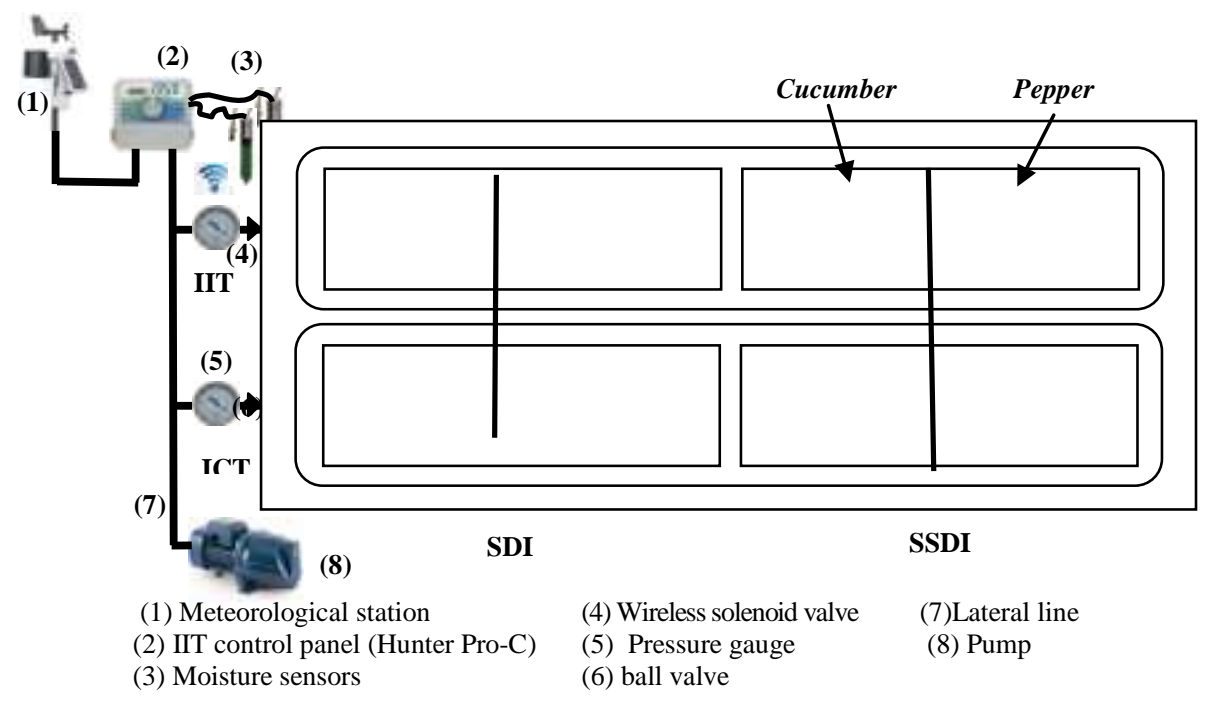

Fig. 1. Field experiment layout

Egypt. J. Soil Sci. 56, No. 4 (2016) 
Soil characteristics

Soil samples were collected for some physical and chemical soil characteristics The methodological procedures were according to methods described by Page et al. (1982) and Klute (1986) (Tables 1\&2)

TABLE 1. Some physical characteristics of experimental soil

\begin{tabular}{|c|c|c|c|c|c|c|c|c|c|c|c|c|}
\hline \multirow{2}{*}{$\begin{array}{c}\text { Soil } \\
\text { depth } \\
\text { (cm) }\end{array}$} & \multicolumn{5}{|c|}{ Particle size distribution \% } & \multirow[b]{2}{*}{$\begin{array}{l}\text { Textural } \\
\text { class }\end{array}$} & \multirow[b]{2}{*}{$\underset{\%}{O M}$} & \multirow[b]{2}{*}{$\begin{array}{c}\rho_{b} \\
\mathrm{~g} / \mathrm{cm}^{3}\end{array}$} & \multirow[b]{2}{*}{$\begin{array}{c}\mathbf{K s} \\
\mathbf{c m} / \mathbf{h}\end{array}$} & \multirow[b]{2}{*}{$\begin{array}{c}\text { FC } \\
\%\end{array}$} & \multirow[b]{2}{*}{$\begin{array}{l}\text { WP } \\
\%\end{array}$} & \multirow[b]{2}{*}{$\underset{\%}{\mathrm{AW}}$} \\
\hline & $\begin{array}{l}\text { C. } \\
\text { sand }\end{array}$ & \begin{tabular}{|c|} 
M. \\
sand
\end{tabular} & $\begin{array}{c}\text { F. } \\
\text { sand }\end{array}$ & Silt & Clay & & & & & & & \\
\hline $0-15$ & 4.51 & 78.37 & 12.89 & 2.71 & 1.52 & $\mathrm{~S}$ & 0.47 & 1.57 & 15.43 & 10.21 & 3.56 & 6.65 \\
\hline $15-30$ & 5.34 & 76.05 & 13.64 & 3.34 & 1.63 & $\mathrm{~S}$ & 0.44 & 1.59 & 15.49 & 9.98 & 3.51 & 6.47 \\
\hline $30-45$ & 5.42 & 73.42 & 15.49 & 4.03 & 1.64 & $\mathrm{~S}$ & 0.38 & 1.61 & 14.74 & 9.70 & 3.36 & 6.34 \\
\hline $45-60$ & 5.84 & 71.75 & 15.77 & 4.91 & 1.73 & $\mathrm{~S}$ & 0.27 & 1.63 & 14.07 & 9.54 & 3.32 & 6.22 \\
\hline
\end{tabular}

TABLE 2. Some chemical characteristics of experimental soil

\begin{tabular}{|c|c|c|c|c|c|c|c|c|c|c|c|c|c|c|c|c|}
\hline \multirow{2}{*}{ 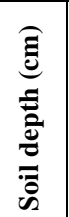 } & \multirow[b]{2}{*}{ 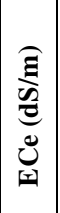 } & \multirow[b]{2}{*}{ \pm} & \multirow[b]{2}{*}{$\begin{array}{l}0 \\
0 \\
\tilde{ల} \\
\tilde{J}\end{array}$} & \multirow[b]{2}{*}{ 兒 } & \multicolumn{8}{|c|}{$\begin{array}{c}\text { Soluble ions (meq/l) in the saturated soil } \\
\text { paste extract }\end{array}$} & \multicolumn{4}{|c|}{$\begin{array}{c}\text { Exchangeable cations } \\
{\text { cmole } \mathrm{kg}^{-1}}^{-1}\end{array}$} \\
\hline & & & & & $\stackrel{+}{\mathbf{z}}$ & $\stackrel{+}{4}$ & ש & $\sum^{+\infty}$ & $\bar{\tau}$ & $\bigcup_{0}^{\infty}$ & ¿ & O্ & ${ }^{+}$ & $\stackrel{+}{4}$ & ש & $\sum^{\ddagger}$ \\
\hline $0-15$ & 2.15 & 7.62 & 2.44 & 6.79 & 9.94 & 1.23 & 5.91 & 4.42 & 10.31 & 2.91 & - & 8.28 & 1.99 & 0.15 & \begin{tabular}{|l|}
1.37 \\
\end{tabular} & \begin{tabular}{|l|}
1.7 \\
\end{tabular} \\
\hline $15-30$ & \begin{tabular}{|l|}
2.38 \\
\end{tabular} & 7.50 & 2.41 & 6.20 & 9.41 & 2.9 & \begin{tabular}{|l|l|}
6.63 \\
\end{tabular} & \begin{tabular}{|l|}
4.86 \\
\end{tabular} & 11.49 & 2.77 & - & 9.54 & 1.69 & 0.31 & \begin{tabular}{|l|}
1.36 \\
\end{tabular} & 1.68 \\
\hline $30-45$ & 2.91 & 7.47 & 2.34 & 6.10 & 9.29 & 4.11 & 8.61 & \begin{tabular}{|l|}
7.09 \\
\end{tabular} & 14.24 & 2.59 & - & 12.27 & 1.37 & 0.36 & 1.46 & 2.00 \\
\hline $45-60$ & 2.95 & \begin{tabular}{|l|}
7.41 \\
\end{tabular} & \begin{tabular}{|l|}
2.29 \\
\end{tabular} & 6.08 & 9.18 & 4.16 & 8.85 & \begin{tabular}{|l|}
7.31 \\
\end{tabular} & 14.46 & 2.58 & - & 12.46 & 1.34 & 0.37 & \begin{tabular}{|l|}
1.47 \\
\end{tabular} & 2.03 \\
\hline
\end{tabular}

Quality of irrigation water

Chemical analyses of the irrigation water were measured according to methods described by Ayers and Westcot (1994).

TABLE 3.Some chemical analysis for irrigation water

\begin{tabular}{|c|c|c|c|c|c|c|c|c|c|c|c|}
\hline \multirow{2}{*}{ Sample } & \multirow{2}{*}{$\mathbf{p H}$} & \multirow{2}{*}{$\begin{array}{c}\mathbf{E C} \\
\mathbf{d S} / \mathbf{m}\end{array}$} & \multirow{2}{*}{$\mathbf{S A R}$} & \multicolumn{3}{|c|}{ Soluble cations, meq/l } & \multicolumn{4}{|c|}{ Soluble anions , meq/l } \\
\cline { 5 - 12 } & & & $\mathbf{N a}^{+}$ & $\mathbf{K}^{+}$ & $\mathbf{C a}^{++}$ & $\mathbf{M g}^{++}$ & $\mathbf{C L}^{-}$ & $\mathbf{H C O}_{\mathbf{3}}^{-}$ & $\mathbf{C O}_{\mathbf{3}}{ }^{-}$ & $\mathbf{S O}_{\mathbf{4}}{ }^{+}$ \\
\hline mean & 7.46 & 1.69 & 1.04 & 2.64 & 1.36 & 12.51 & 0.39 & 6.61 & 2.02 & 0 & 8.27 \\
\hline
\end{tabular}

Irrigation water requirements

The amounts of applied irrigation water shown in Tables (5\&6) were calculated by using the equation:

- Applied irrigation water $\left.I R_{100 \%}=(E T c-p e) K r / E a\right)+L R$ $(\mathrm{mm} /$ period) (Keller and Karmeli , 1974)

where: $K r$ : correction factor for limited wetting at cucumber and pepper percent round coverage by canopy $80 \%, K r=0.90$. (Smith, 1992). $E a$ : irrigation efficiency for surface drip (85\%) (Allen et al., 1998).

$P e:$ effective rainfall, $0 \mathrm{~mm}$.

$L R$ : leaching requirements, for cucumber and pepper (16 and 15\%) (0.16 and $0.15 \mathrm{x}$ ETc), $\mathrm{mm}$.

Egypt. J. Soil Sci. 56, No. 4 (2016) 
- Crop evapotranspiration ETc $=K c_{F A O}$. ETo $\quad\left(\mathrm{mm} \mathrm{day}^{-1}\right)$

Allen et al., 1998)

where: $K c_{F A O}$ : crop coefficient from FAO No.(56).

ETo : reference crop evapotranspiration, $\mathrm{mm} \mathrm{day}^{-1}$.

TABLE 4. Calculation reference evapotranspiration ( $\mathrm{mm} / \mathrm{day})$ through cucumber and pepper growth period

\begin{tabular}{|c|c|c|c|c|c|}
\hline Month & August & September & October & November & December \\
\hline ETo, mm/day & 7.27 & 5.00 & 3.98 & 3.15 & 2.43 \\
\hline
\end{tabular}

- Leaching requirement $L R=E C_{w} /\left(5\left(E C_{e}\right)-E C_{w}\right) \times 100$

(Allen et al., 1998)

where: $E C w$ : electrical conductivity of the irrigation water, $\mathrm{dS} \mathrm{m} \mathrm{m}^{-1}$.

ECe : average electrical conductivity of the soil solution extract, $\mathrm{dS} \mathrm{m}^{-1}$.

TABLE 5. Applied irrigation water $I R(\mathrm{~mm} /$ period) based on ETc technique for cucumber

\begin{tabular}{|c|c|c|c|c|c|}
\hline Stages & Initial & Develop. & Mid & Late & Seasonal \\
\hline Period length (day) & 20 & 30 & 40 & 15 & 105 \\
\hline Kc $_{\text {FAO }}$ & 0.60 & 0.80 & 1.00 & 0.75 & ------- \\
\hline ETo (mm) & 145.4 & 156.81 & 159.03 & 46.95 & 508.19 \\
\hline ETc (mm) & 87.24 & 125.45 & 159.03 & 35.21 & 406.93 \\
\hline IR (mm) & 106.14 & 152.62 & 193.48 & 42.84 & 495.08 \\
\hline
\end{tabular}

Convert $\mathrm{mm}$ to $\mathrm{m}^{3}=$ water per $\mathrm{mm}$ depth $*$ Area (3.57 not 4.2 for drip irrigation)

TABLE 6. Applied irrigation water IR ( $\mathrm{mm} /$ period) based on $E T c$ technique for pepper

\begin{tabular}{|c|c|c|c|c|c|}
\hline Stages & Initial & Develop. & Mid & Late & Seasonal \\
\hline Period length (day) & 30 & 35 & 40 & 20 & 125 \\
\hline KcFAO & 0.6 & 0.83 & 1.05 & 0.9 & ------- \\
\hline ETo (mm) & 202.21 & 163.78 & 142.2 & 54.9 & 563.09 \\
\hline ETc (mm) & 121.33 & 135.94 & 149.31 & 49.41 & 455.98 \\
\hline IR (mm) & 146.61 & 164.27 & 180.43 & 59.71 & 551.02 \\
\hline
\end{tabular}

- Actual evapotranspiration $E T a=\left(M_{2} \%-M_{1} \%\right) / 100 . d_{b} . D \quad(\mathrm{~mm})$

( Doorenbos and Pruitt, 1984)

where: $M_{2}$ : moisture content after irrigation $\%$.

$M_{l}$ : moisture content before irrigation $\%$.

$d_{b} \quad$ : specific density of soil .

D : mean depth, mm. 
Irrigation efficiency

- Water use efficiency WUE, $\left(\mathrm{kg} \mathrm{m}^{-3}\right)=Y \mathrm{a} / E T a$

(Howell, 2001)

where: Ya : economic yield of the crop, $\left(\mathrm{kg} \mathrm{fed}^{-1}\right)$.

- Irrigation water use efficiency IWUE, $\left(\mathrm{kg} \mathrm{m}^{-3}\right)=Y \mathrm{a} / I R \quad$ (Michael, 1978) where: $I R$ : seasonal amount of applied irrigation water, $\left(\mathrm{m}^{3}\right)$

\section{Results and Discussion}

Effect of IIT technique under SDI and SSDI on some growth parameters

Data in Table 7 presented that the intelligent irrigation technique IIT under sub-surface drip irrigation SSDI recorded the maximum values of LA (142.35 $\left.\mathrm{cm}^{2}\right), \mathrm{L}(19.87 \mathrm{~cm}), \mathrm{D}(13.82 \mathrm{~cm})$ and TSS (7.37\%) except pH of juice (3.52) for cucumber, LA $\left(116.40 \mathrm{~cm}^{2}\right), \mathrm{L}(14.68 \mathrm{~cm}), \mathrm{D}(7.15 \mathrm{~cm})$ and TSS $(11.12 \%)$ except $\mathrm{pH}$ of juice (4.49) for pepper. While the irrigation control technique ICT under surface drip irrigation SDI recorded the minimum values of LA $\left(126.71 \mathrm{~cm}^{2}\right), \mathrm{L}$ $(16.62 \mathrm{~cm}), \mathrm{D}(11.59 \mathrm{~cm})$ and TSS $(5.75 \%)$ except $\mathrm{pH}$ of juice $(4.21)$ for cucumber, LA $\left(98.26 \mathrm{~cm}^{2}\right), \mathrm{L}(11.62 \mathrm{~cm}), \mathrm{D}(5.68 \mathrm{~cm})$ and TSS $(8.19 \%)$ except $\mathrm{pH}$ of juice (5.55) for pepper. The results indicated that the IIT under SSDI significantly increased of LA, L, D and TSS by $5,11,7$ and $12 \%$ for cucumber, 8 , 13,9 and $15 \%$ for pepper respectively. On the other hand, $\mathrm{pH}$ of juice which decreased by 8 and $11 \%$ for cucumber and pepper compared to that under ICT at the same treatment. These results are in agreement with Yazar et al. (1999) and Al-Ghobari et al. (2013).

TABLE 7. Effect of IIT under SDI and SSDI on some growth parameters of studied crops

\begin{tabular}{|c|c|c|c|c|c|c|c|}
\hline Crops & $I S$ & $A I T$ & $\begin{array}{c}L A \\
\left(\mathrm{~cm}^{2}\right)\end{array}$ & $\begin{array}{c}L \\
(\mathrm{~cm})\end{array}$ & $\begin{array}{c}D \\
(\mathrm{~cm})\end{array}$ & $\begin{array}{c}T S S \\
(\%)\end{array}$ & $p H$ \\
\hline \multirow{4}{*}{ 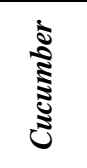 } & \multirow{2}{*}{$S D I$} & $I I T$ & 130.69 & 17.89 & 12.21 & 6.24 & 3.98 \\
\hline & & $I C T$ & 126.71 & 16.62 & 11.59 & 5.75 & 4.21 \\
\hline & \multirow{2}{*}{ SSDI } & $I I T$ & 142.35 & 19.87 & 13.82 & 7.37 & 3.52 \\
\hline & & $I C T$ & 134.94 & 17.90 & 12.91 & 6.59 & 3.79 \\
\hline \multirow{3}{*}{$L S D$} & \multirow{3}{*}{$(0.05)$} & $I S$ & 11.67 & 0.75 & 1.34 & 0.47 & 0.30 \\
\hline & & $A I T$ & 5.57 & 1.34 & 1.00 & 0.43 & 0.37 \\
\hline & & $I S X A I T$ & 7.87 & 1.90 & 1.42 & 0.61 & 0.53 \\
\hline \multirow{4}{*}{$\frac{\grave{\Xi}}{2}$} & \multirow{2}{*}{$S D I$} & $I I T$ & 103.58 & 12.73 & 6.14 & 9.25 & 5.13 \\
\hline & & $I C T$ & 98.26 & 11.62 & 5.68 & 8.19 & 5.55 \\
\hline & \multirow{2}{*}{ SSDI } & $I I T$ & 116.40 & 14.68 & 7.15 & 11.12 & 4.49 \\
\hline & & $I C T$ & 107.70 & 12.95 & 6.54 & 9.69 & 4.97 \\
\hline \multirow{3}{*}{$L S D$} & \multirow{3}{*}{$(0.05)$} & $I S$ & 4.88 & 1.92 & 0.09 & 0.69 & 0.67 \\
\hline & & $A I T$ & 7.43 & 1.34 & 0.31 & 0.59 & 0.25 \\
\hline & & $I S X A I T$ & 10.51 & 1.89 & 0.44 & 0.84 & 0.36 \\
\hline
\end{tabular}

Egypt. J. Soil Sci. 56, No. 4 (2016) 
Meanwhile, applied irrigation water by IIT under SSDI significantly increased by $8,10,12$ and $15 \%$ for LA, L, D and TSS of cucumber respectively, and pH of juice which decreased by $11.6 \%$ compared to that under SDI. Also, data recorded that the IIT under SSDI significantly increased by $11,13,14$ and 15 to $17 \%$ for LA, L, D and TSS of pepper respectively, and $\mathrm{pH}$ of juice which decreased by $12.5 \%$ compared to that under SDI. These increases may be attributed to the SSDI lines were covered with soil that decrease the amounts of lost water through compared to that of SDI (Hassanli et al., 2009).

\section{Effect of IIT technique under SDI and SSDI on marketable yield}

Data in Table 8 reported that the maximum values of marketable yield $\mathrm{Ym}$ for cucumber and pepper were (30.96 and $9.56 \mathrm{Mg} \mathrm{fed}^{-1}$ ) under IIT and SSDI. While, the minimum values were (24.13 and $\left.7.05 \mathrm{Mg} \mathrm{fed}^{-1}\right)$ for both crops under ICT and SDI. The results showed that the IIT under SSDI significantly increased of Ym by 12 and $13 \%$ for both crops compared to that under ICT at the same treatment. These increasing may be attributed to the smart controllers integrate many disciplines that add needed water amounts leading to significant improvement in crop production. In addition the IIT Improved Irrigation scheduling based upon crop water status needed is in. These results are in harmony with the finding of Norum and Adhikari (2009) Al-Ghobari et al. (2013) and Mohamed et al. (2013). Meanwhile, applied irrigation water by IIT under SSDI was significantly increased of Ym by (15 and 19\%) for both crops compared to that under SDI (Hassanli et al., 2009).

TABLE 8. Effect of IIT under SDI and SSDI on IR, ETa, Ym, WUE and IWUE of studied crops

\begin{tabular}{|c|c|c|c|c|c|c|c|}
\hline Crops & $I S$ & $A I T$ & $\begin{array}{c}Y m \\
\left(\text { Mg fed }^{-1}\right)\end{array}$ & $\begin{array}{c}\text { IR } \\
\left(m m \text { Season }^{-1}\right)\end{array}$ & $\begin{array}{c}\text { ETa } \\
\left(\text { mm Season }^{-1}\right)\end{array}$ & $\begin{array}{c}\text { WUE } \\
\left(\mathrm{kg} \mathrm{m}^{-3}\right)\end{array}$ & $\begin{array}{l}\text { IWUE } \\
\left(\mathrm{kg} \mathrm{m}^{-3}\right)\end{array}$ \\
\hline \multirow{4}{*}{ 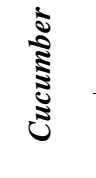 } & \multirow{2}{*}{$S D I$} & IIT & 26.47 & 402.83 & 373.71 & 16.86 & 15.65 \\
\hline & & $I C T$ & 24.13 & 495.08 & 421.46 & 13.63 & 11.60 \\
\hline & \multirow{2}{*}{$\begin{array}{l}S S \\
D I\end{array}$} & IIT & 30.96 & 370.64 & 331.97 & 22.21 & 19.89 \\
\hline & & $I C T$ & 27.68 & 495.08 & 385.62 & 17.09 & 13.31 \\
\hline \multirow{3}{*}{$L S D$} & \multirow{3}{*}{$(0.05)$} & $I S$ & 0.87 & 64.70 & 8.29 & 0.97 & 2.30 \\
\hline & & $A I T$ & 1.76 & 30.94 & 47.95 & 2.14 & 1.29 \\
\hline & & $\begin{array}{l}\text { IS X } \\
\text { AIT }\end{array}$ & 2.49 & 43.76 & 67.81 & 3.02 & 1.82 \\
\hline \multirow{4}{*}{ 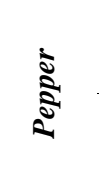 } & \multirow{2}{*}{$S D I$} & $I I T$ & 7.79 & 472.15 & 421.41 & 4.40 & 3.93 \\
\hline & & $I C T$ & 7.05 & 551.02 & 485.28 & 3.46 & 3.05 \\
\hline & \multirow{2}{*}{$\begin{array}{l}S S \\
D I\end{array}$} & $I I T$ & 9.56 & 445.97 & 367.53 & 6.19 & 5.10 \\
\hline & & $I C T$ & 8.49 & 551.02 & 435.85 & 4.64 & 3.67 \\
\hline \multirow{3}{*}{$L S D$} & \multirow{3}{*}{$(0.05)$} & $I S$ & 0.54 & 46.31 & 26.90 & 0.17 & 0.68 \\
\hline & & $A I T$ & 0.70 & 29.67 & 48.65 & 0.55 & 0.59 \\
\hline & & $\begin{array}{l}I S X \\
A I T\end{array}$ & 0.99 & 41.95 & 68.80 & 0.78 & 0.83 \\
\hline
\end{tabular}


Effect of IIT technique under SDI and SSDI on amount of irrigation water

Data in Table 8 \& Fig. 2 for cucumber and pepper crops showed that the minimum values of applied irrigation water IR for Initial, development, midseason, late-season growth stages and the seasonal were $(65.21,129.56,151.18$, 24.69 and $370.64 \mathrm{~mm})$ for cucumber, $(105.12,141.65,163.39,35.81$ and $445.97 \mathrm{~mm})$ for pepper respectively, under IIT and SSDI. While, the maximum values of IR for, the same growth stages were $(106.14,152.62,193.48,42.84$ and $495.08 \mathrm{~mm})$ for cucumber, $(146.61,164.27,180.43,59.71$ and $551.02 \mathrm{~mm})$ for pepper respectively, under ICT at both irrigation systems. The results reported that the use of IIT under SSDI reduce the amount of irrigation water IR added for cucumber and pepper by 34 and $24 \%$ compared to that under ICT at the same treatment.
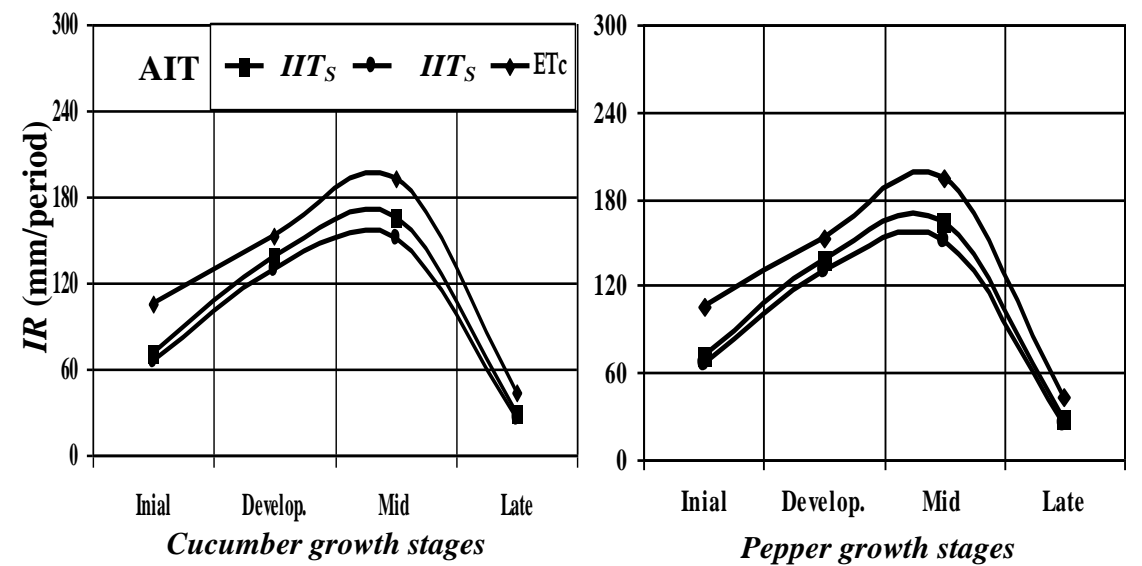

Fig. 2. Effect of IIT technique under SDI and SSDI on amount of irrigation water

The results reported that the use of IIT under SSDI reduce the amount of irrigation water IR added for cucumber and pepper by 34 and $24 \%$ compared to that under ICT at the same treatment. These reduction may be attributed to the intelligent irrigation technique (IIT) as it change irrigation frequency stage could significantly affect the available soil water during vegetables growing seasons. In addition to that for saving water in the irrigation system based on the climatological parameters, needed water can be given for the plants, based on its growth stages are in. These results agreement to with (Ghobari et al. (2013) Mohamed et al. (2013) and Anand and Perinbam (2014). Meanwhile, applied irrigation water by IIT under SSDI was reduced by about 8 and $6 \%$ for cucumber and pepper compared to that under SDI (Hassanli et al., 2009).

\section{Effect of IIT technique under SDI and SSDI on actual evapotranspiration}

Data in Table 8 \& Fig. 3 and 4 for cucumber and pepper crops showed that the minimum values of the actual evapotranspiration ETa for, Initial, development, mid-season, late-season growth stages and the seasonal were

Egypt. J. Soil Sci. 56, No. 4 (2016) 
(49.61, 117.45, 143.12, 21.97 and $331.97 \mathrm{~mm}$ ) for cucumber, (56.23, 129.47, $154.19,27.64$ and $367.53 \mathrm{~mm}$ ) for pepper respectively, under IIT and SSDI. While, the maximum values of ETa for, the same growth stages were $(61.37$, $147.75,172.53,39.81$ and $421.46 \mathrm{~mm}$ ) for cucumber, $(89.60,155.46,187.73$, 52.49 and $485.28 \mathrm{~mm}$ ) for pepper respectively, under ICT and SDI. The results concluded that the IIT under SSDI reduced actual evapotranspiration for cucumber and pepper by 16 and $19 \%$ compared to that under ICT at the same treatment. This reduction may be attributed to that the intelligent irrigation technique (IIT) regulates the desired moisture level in agricultural soil by regulating the irrigation pump, on or off, based on the sensor readings. These results agree with that of Patil et al., 2012 and Mohamed et al. (2013). In addition, the applied irrigation water by IIT under SSDI reduced the ETa consumed cucumber and pepper by 11 and $13 \%$ compared to that under SDI (Hassanli et al., 2009).
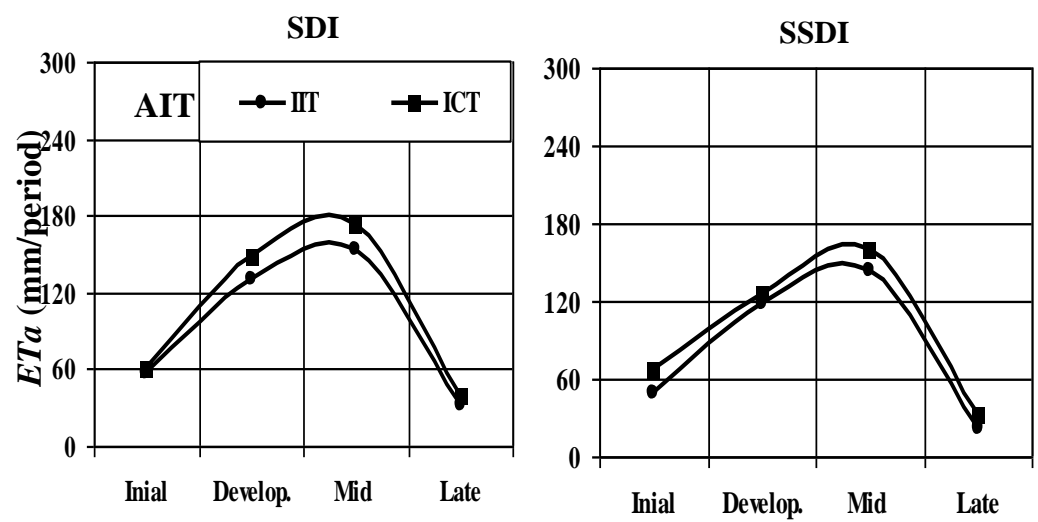

Cucumber growth stages

Fig.3. Effect of IIT technique under SDI and SSDI on actual evapotranspiration for cucumber

SDI

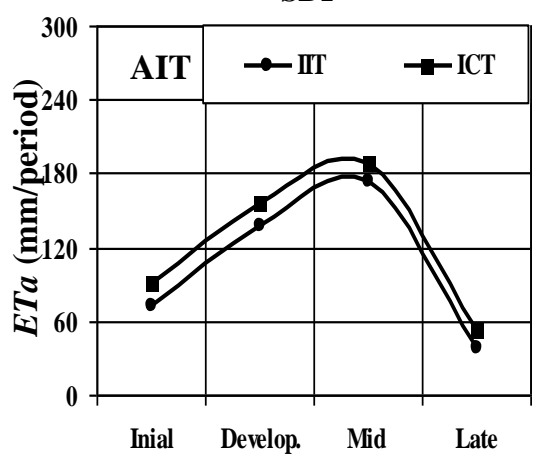

SSDI

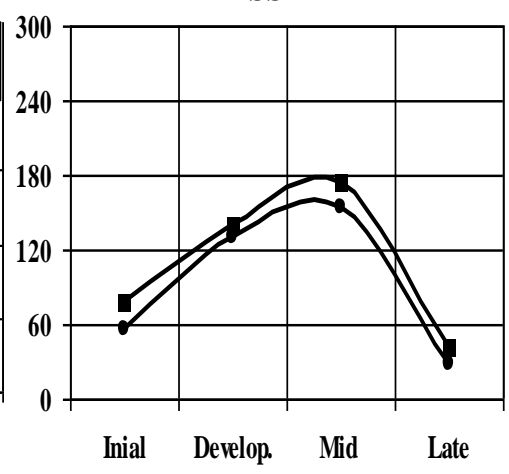

Pepper growth stages

Fig.4. Effect of IIT technique under SDI and SSDI on actual evapotranspiration for pepper

Egypt. J. Soil Sci. 56, No. 4 (2016) 


\section{Effect of IIT technique under SDI and SSDI on water use efficiency}

Data in Table 8 illustrate that the maximum values of water use efficiency WUE and irrigation water use efficiency IWUE were 22.21 and $19.89 \mathrm{~kg} \mathrm{~m}^{-3}$ for cucumber, 6.19 and $5.10 \mathrm{~kg} \mathrm{~m}^{-3}$ for pepper under IIT and SSDI. While, the minimum values of WUE and IWUE were 13.63 and $11.60 \mathrm{~kg} \mathrm{~m}^{-3}$ for cucumber, 3.46 and $3.05 \mathrm{~kg} \mathrm{~m}^{-3}$ for pepper under ICT and SDI. The results revealed that the IIT under SSDI significantly increased of WUE and IWUE by 30 and $49 \%$ for cucumber, 33 and 39\% for pepper compared to that under ICT at the same treatment. These results may be attributed to the intelligent irrigation technique which that lead to increased values of marketable yield and reduce the seasonal amount of irrigation water at the same time. These results agree with Mohamed et al. (2013 and Al-Ghobari et al. (2013) data. Meanwhile, the applied irrigation water by IIT under SSDI significantly increased the WUE and IWUE by about 24 and $21 \%$ for cucumber, 29 and $23 \%$ for pepper compared to that under SDI (Hassanli et al., 2009).

\section{Conclusions}

Conserving water is very important in areas experiencing severe drought, such as Egypt. This study has demonstrated possible modifications and developments to the proposed system for improved and more efficient scheduling control. It can be concluded that an economic amount benefit can be achieved with saving large amounts of irrigation water when applying advance scheduling irrigation techniques such as IIT under arid conditions. So, it can generally recommended to use intelligent irrigation technique under subsurface drip irrigation for saving applied irrigation water by about (34 and 24\%) for cucumber and pepper respectively, compared to that under ICT and increasing the production by about (12 and 13\%) for cucumber and pepper respectively, under sandy soil conditions.

\section{References}

Allen, R.G., Smith, M.; Perrier, A. and Pereira, L.S. (1998) Crop Evapotranspiration, Guidelines for computing crop water requirements. FAO Irrigation and Drainage Paper No.56, FAO, Rome, Italy: 1-79.

Anand, J. and Perinbam J.R.P. (2014) Automatic Irrigation System using Fuzzy Logic. CG College of Technology, Chennai, Tamil Nadu, India, AEIJMR 2 (8) 2348 - 6724.

Ayers, R.S. and Westcot, D.W. (1994) Water Quality for Agriculture, Irrigation and Drainage Paper No 29, FAO, Rome, Italy.

Al-Ghobari, H.M.; Mohamed, F.S. and Abdalla El Marazky, M.S. (2013) "Effect of intelligent irrigation on water use efficiency of wheat crop in arid region". Dept. of Agric. Eng., College of Food and Agric. Sci., King Saud. The Journal of Animal \& Plant Sciences, 23(6), 1691-1699.

Acar, B., Topak, R., and Direk, M. (2010) "Impacts of Pressurized Irrigation Technologies on Efficient Water Resources Uses in Semi-Arid Climate of Konya Basin of Turkey" Int. J. of Sustainable Water \& Environmental Systems 1(1), 1-4.

Egypt. J. Soil Sci. 56, No. 4 (2016) 
Dassanayake, D.K., Dassanayake, H., Malano, G.M., Dunn Douglas, P. and Langford, J. (2009) Water saving through smarter irrigation in Australian dairy farming: use of intelligent irrigation controller and wireless sensor network. $18^{\text {th }}$ World IMACS/MODSIM Congress, Cairns, Australia, pp 4409-4417.

Doorenbos, J. And Pruitt, W.O. (1984)Crop Water requirements - Guidelines for predicting crop requirements. FAO Irrigation and Drainage Paper No.24, FAO, Rome, Italy: 45-90.

Mohamed, F.S., Al-Ghobari, H.M. and Abdalla El Marazky M.S. (2013) "Adoption of an intelligent irrigation scheduling technique and its effect on water use efficiency for tomato crops in arid regions". Dept. of Agric. Eng., College of Food and Agric. Sci., King Saud. AJCS 7(3), 305-313.

Hassanli, A.M., Ebrahimizadeh, M.A. and Beecham, S. (2009) The effects of irrigation methods with effluent and irrigation scheduling on water use efficiency and corn yields in an arid region. Agricultural Water Management. (96), 93- 99.

Howell, T.A. (2001) Enhancing water use efficiency in irrigated agriculture. Agronomy J. Abst., (93), $281-289$.

Keller, J. and Karmeli, D. (1974) Trickle irrigation design parameters. ASAE, 17 (4), 678-684.

Klute, A. (1986) Methods of soil analysis, Part (1). Physical and Mineralogical MethodsAgronomy monograph No. 9 ( $2^{\text {nd }}$ Edition). ASA and SSSA, Madison, WI, USA: 635 - 660.

Michael, A. (1978) Irrigation and Theory Practice. Vikas Pub. House PVT LTD, New Delihi.

Michael, D. and Dukes, M.D. (2008) Water conservation potential of smart irrigation controllers. In: $5^{\text {th }}$ National decennial irrigation conference proceedings, Phoenix convention center, Phoenix, AZ, USA IRR10-9520. ASABE 2950 Niles Road, St. Joseph, MI 49085.

Norum, M.N. and Adhikari, D. (2009) Smart irrigation system controllers. In: $7^{\text {th }}$ World Congress on computers in agriculture conference proceedings, Reno, Nevada. ASABE, St. Joseph, Michigan.

Nautiyal, M., Grabow, G., Miller, G. and Huffman, R.L. (2010) Evaluation of two smart irrigation technologies in Cary, North Carolina. ASABE Annual International Meeting.David L. Lawrence Convention Center. Pittsburgh, Pennsylvania: 20-23.

Page, A.L., Miller, R.H. and Keeney D.R. (1982) Methods of Soil Analysis, part 2. Chemical and Microbiological Properties. Amer. Soc. of Agron, Madison, Wisconsin, USA.

Patil, P., Kulkarni, U., Desai, B.L., Benagi, V.I. and Naragund, V.B. (2012) Fuzzy logic based irrigation control system using wireless sensor network for precision agriculture. Agro-Informatics and Precision Agriculture, India. 3 (7), 262-269.

Smith, M. (1992) CROPWAT A Computer Program for Irrigation Planning and Management and ETo calculation using Penman-Montieth method, FAO Irrigation and Drainage, Rome, Italy: (46), 112-140. 
Snedecor, G.W. and Cochran, W.G. (1982) Statistical Methods. Seventh edition, IOWA State Univ. Press Ames., USA.: 145-166.

Yazar, A., Howell, A.T., Dusek, D.A. and Copeland, K.S., 1999. Evaluation of crop water stress index for LEPA irrigated corn. Irrig. Sci. (18), 171-180.

(Received: 26/7/2016;

Accepted: 16/11/2016

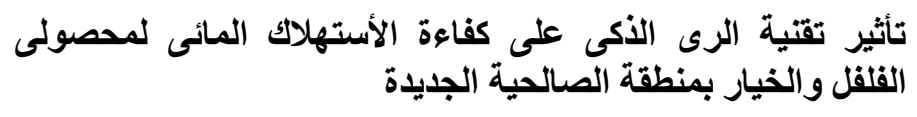

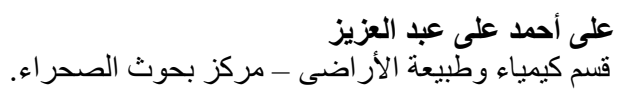

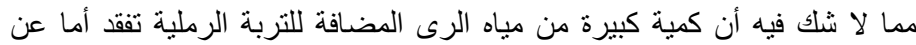

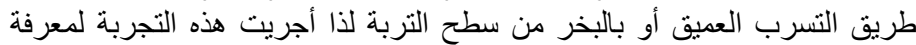

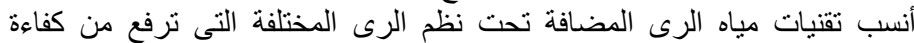

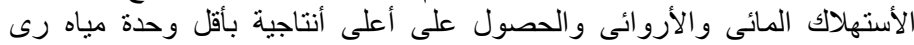

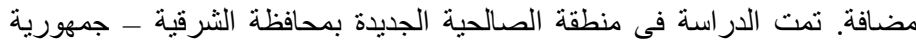

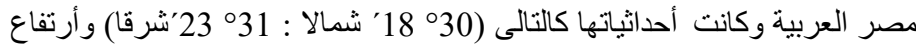
27 مثر فوق مستوى سطح البحرخلال الموسم الصيفى 2015 نم أستخدام التصميم

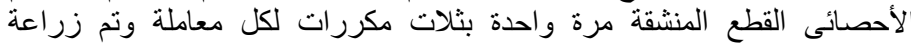

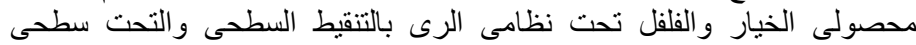

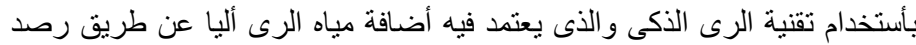

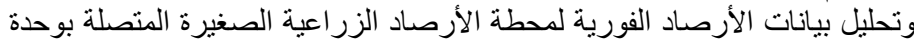

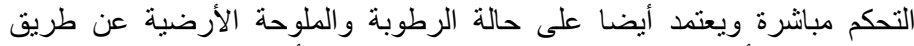

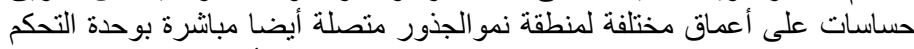

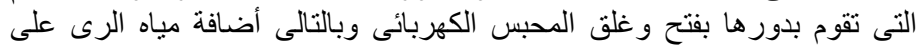

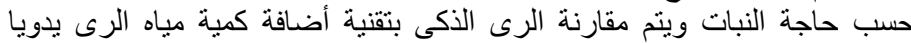

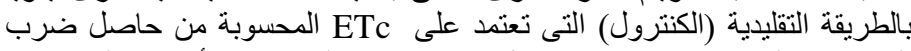

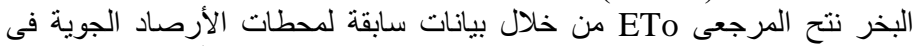

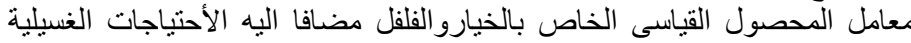

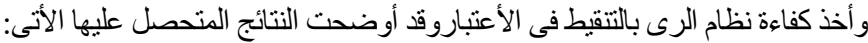

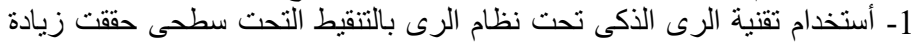

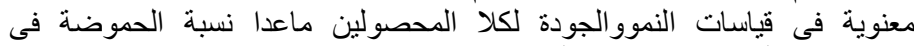

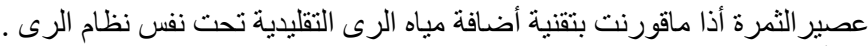

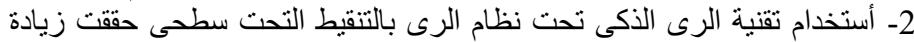

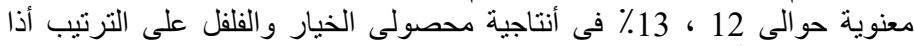

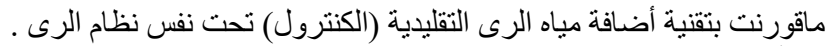

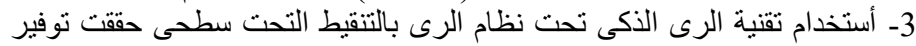

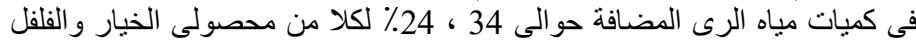
على الترتيب أذا ماقورنت بتقنية أضافة مياه الرى التقليدية (الكنترول) تحت نفس

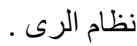

Egypt. J. Soil Sci. 56, No. 4 (2016) 
4- أستخدام تقنية الرى الذكى تحت نظام الرى بالتنقيط التحت سطحى حققت زيادة

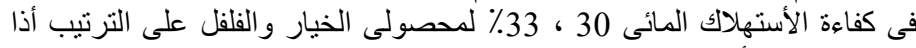

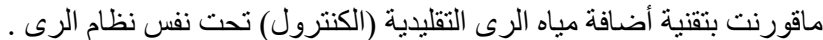

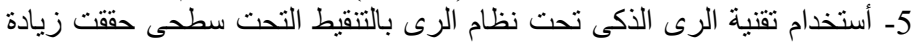

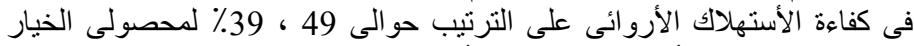

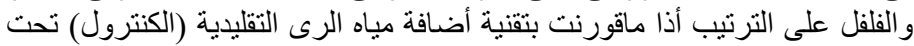

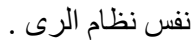

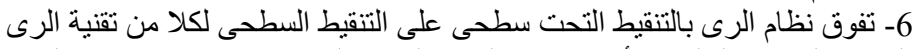

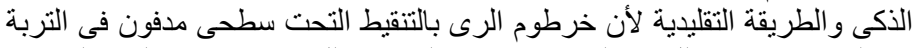

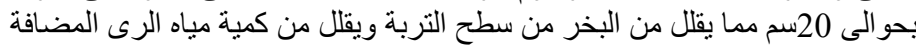
والأستهلاك المائى الفعلى لكلا المحصولين وبالتالى زيادة الأنتاجية .

عموما يمكن التوصية بأستخدام تقنية الرى الأكى تحت نظام الرى بالتنقيط

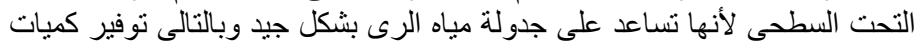

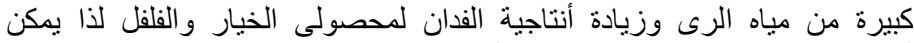

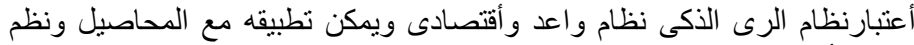

